\title{
NEW FAUNISTICAL AND TAXONOMIC DATA ON ORIBATID MITES (ACARI, ORIBATIDA) FROM THE AFROTROPICAL REGION
}

\author{
Sergey G. Ermilov ${ }^{1^{*}}$ and Marek Bąkowski
}

\author{
${ }^{1} \mathrm{X}$-BIO Institute, Tyumen State University, Tyumen, Russia \\ ${ }^{2}$ Institute of Environmental Biology, Adam Mickiewicz University, Poznań, Poland \\ *corresponding author; e-mail: ermilovacari@yandex.ru
}

\begin{abstract}
The present study is based on oribatid mite materials collected in Ghana and Mozambique. A list of identified taxa, including 13 species from 12 genera and nine families, is provided. Of these, nine species, five genera and two families are recorded for the first time in the fauna of the above countries. One new species-Zetorchella ghanaensis sp.n. (Caloppiidae)-is described.
\end{abstract}

KEY WORDS: Mite fauna, new record, taxonomy, morphology, Zetorchella, Ghana.

DOI: $10.21684 / 0132-8077-2021-29-2-135-140$

\section{INTRODUCTION}

This work is based on oribatid mite materials (Acari, Oribatida), which were collected during the expeditions in the Afrotropical region (Ghana and Mozambique). The primary goal of our paper is to present a list of the identified taxa with notes on new findings.

The secondary goal of this paper is to describe and illustrate a new species belonging to the genus Zetorchella Berlese, 1916 (family Caloppiidae) that was collected in Ghana. Zetorchella was proposed by Berlese (1916), with Chaunoproctus cancellatus Pearce, 1906 as type species. The genus comprises 25 species that are distributed in the Afrotropical and Oriental regions, namely in Guyana and Japan (Subías 2004, online version 2021; Ermilov and N'Dri 2019; Ermilov et al. 2021). This paper presents the first record of Zetorchella in the fauna of Ghana. The revised generic diagnosis and an identification key to the species of Zetorchella from the Afrotropical region were presented by Ermilov and N'Dri (2019).

At present, the oribatid mite fauna of Ghana and Mozambique are insufficiently studied, and only a few taxa are known (e.g., Wallwork 1962; Niedbała, 2008; Ermilov and Bąkowski 2021).

\section{MATERIALS AND METHODS}

Specimens. Substrate samples containing oribatid mites were collected in four localities:

(1) Mozambique, Nampula Province, Island of Mozambique District, Lumbo, $15^{\circ} 03^{\prime} 16.53^{\prime \prime} \mathrm{S}$, $40^{\circ} 40^{\prime} 27.75^{\prime \prime} \mathrm{E}, 14 \mathrm{~m}$ a.s.1., dead wood in shrubs, 10 Jul. 2021 (collected by Marek Bąkowski); (2) Mozambique, Sofala Province, Gorongosa District, Gorongosa National Park, Chitengo Camp, $18^{\circ} 58^{\prime} 45.62^{\prime \prime} \mathrm{S}, 34^{\circ} 21^{\prime} 7.70^{\prime \prime} \mathrm{E}, 38 \mathrm{~m}$ a.s.1., dead wood in Miombo forest, 17-23 Apr. 2016 (col- lected by Marek Bąkowski); (3) Mozambique, Sofala Province, Cheringoma District, near Pauei, $18^{\circ} 25^{\prime} 30.61^{\prime \prime} \mathrm{S}, 35^{\circ} 20^{\prime} 54.25^{\prime \prime} \mathrm{E}, 152 \mathrm{~m}$ a.s.1., leaf litter in Miombo forest, 14-19 Apr. 2018 (collected by Marek Bąkowski); (4) Ghana, Birim North District, Mamang, River Forest Reserve, $06^{\circ} 15^{\prime} 02^{\prime \prime} \mathrm{N}, 01^{\circ} 02^{\prime} 25.7^{\prime \prime} \mathrm{W}, 130 \mathrm{~m}$ a.s. 1. , leaf litter in forest, 31 Aug.-4 Sept. 2006 (collected by Marek Bąkowski). In case of the sites 1-3, mites were extracted using Berlese's funnels with electric lamps $(25 \mathrm{~W})$ in laboratory conditions during six days and preserved in $75 \%$ of ethanol. In case of the site 4 , the mini-Winkler extractor was used in the field - this technique addresses the ground and leaf litter-inhabiting fauna. Detailed description of the Mamang, River Forest Reserve and of the field study are provided in McCullough et al. (2008).

Observation and documentation. Specimens were mounted in lactic acid on temporary cavity slides for measurement and illustration. Body length was measured in lateral view, from the tip of the rostrum to the posterior edge of the gastronotum. Notogastral width refers to the maximum width of the notogaster in dorsal view. Lengths of body setae were measured in lateral aspect. All body measurements are presented in micrometers $(\mu \mathrm{m})$. Formulas for leg setation are given in parentheses according to the sequence trochanter-femur-genu-tibia-tarsus (famulus included). Formulas for leg solenidia are given in square brackets according to the sequence genu-tibia-tarsus. Drawings were made with a camera lucida using a Leica transmission light microscope "Leica DM 2500". SEM micrographs were made with the aid of a JEOL-JSM-6510LV SEM microscope.

Terminology. General morphological terminology used in this paper mostly follows that of 
F. Grandjean: see Travé and Vachon (1975) for references, Norton (1977) for leg setal nomenclature, and Norton and Behan-Pelletier (2009) for overview.

Abbreviations. Prodorsum: lam-lamella; tlam - translamella; slam — sublamella; $A l$ - sublamellar porose area; ro, le, in, $b s$, ex - rostral, lamellar, interlamellar, bothridial, and exobothridial seta, respectively; $t u$-tutorium; $D$-dorsophragma; $P$ pleurophragma. Notogaster: $A a, A 1, A 2, A 3, A 4$ - porose areas; $c, l a, l m, l p, h, p$ - setae; ia, im, ip-lyrifissures; gla -opisthonotal gland opening. Gnathosoma: $a, m, h$-subcapitular setae; or-adoral seta. Epimeral and lateral podosomal regions: $1 a-c, 2 a, 3 a-c$, $4 a-c$ - epimeral setae; $P d I, P d I I$ - pedotectum I, II, respectively; dis-discidium; $c p$-circumpedal carina. Anogenital region: $g$, ag, an, ad-genital, aggenital, anal, and adanal setae, respectively; iadadanal lyrifissure. Legs: Tr, $\mathrm{Fe}, \mathrm{Ge}, \mathrm{Ti}, \mathrm{Ta}$ - trochanter, femur, genu, tibia, tarsus, respectively; $p a-$ porose area; $\omega, \varphi, \sigma$-solenidia; $\varepsilon$-famulus; $d, l, v, b v$, $e v, f t, t c, i t, p, u, a, s, p v, p l$-setae.

\section{LIST OF IDENTIFIED TAXA*}

\section{Trhypochthoniidae}

Archegozetes magnus (Sellnick, 1925): 3 (1 ex.). Distribution: Pantropical region. New record of the genus and species in Mozambique.

\section{Otocepheidae}

Pseudotocepheus pygmaeus Balogh, 1962: 2 (1 ex.). Distribution: Madagascar. New record of the genus and species in Mozambique.

\section{Scutoverticidae}

Ethiovertex macrosetosus Mahunka, 1982: 2 (1 ex.). Distribution: eastern Africa. New record of the family, genus and species in Mozambique.

\section{Caloppiidae}

Zetorchella sp.n.: 4 (4 ex.). New record of the family and genus in Ghana.

\section{Mochlozetidae}

Unguizetes yemeniticus Mahunka, 2000: 3 (1 ex.). Distribution: Ethiopian region.

\section{Scheloribatidae}

Scheloribates aethiopicus Mahunka, 1982: 2 (3ex.). Distribution: Ethiopian region, Canary Islands. New record of the species in Mozambique.

*Distribution: mostly from Subías (online version 2021). Ptyctimous mites not included. All examined specimens (except holotype) are deposited in the collection of the Tyumen State University Museum of Zoology, Tyumen, Russia. References for the original descriptions of species are not presented in the References section.
Scheloribates elsi Pletzen, 1965: 1 (2 ex.). Distribution: Ethiopian region. New record of the species in Mozambique.

\section{Haplozetidae}

Rostrozetes ovulum (Berlese, 1908): 1 (3 ex.). Distribution: Tropical and Subtropical regions.

\section{Galumnidae}

Allogalumna oromiaensis Ermilov, 2019: 1 (4 ex.). Distribution: Ethiopia. New record of the species in Mozambique.

Galumna wojciechniedbalai Ermilov, 2012: 1 (5 ex.). Distribution: Zambia. New record of the species in Mozambique.

Pergalumna somalica (Berlese, 1916): 1 (1 ex.). Distribution: Somalia. New record of the species in Mozambique.

Pilogalumna kimberleyensis Engelbrecht, 1972: 1 (1 ex.). Distribution: South Africa. New record of the genus and species in Mozambique.

\section{Galumnellidae}

Galumnella subareolata Mahunka, 1969: 1 (30 ex.). Distribution: Ethiopian region.

\section{TAXONOMY}

Family Caloppiidae

Genus Zetorchella Berlese, 1916

Type species: Chaunoproctus cancellatus

Pearce, 1906

\section{Zetorchella ghanensis sp. $\mathbf{n}$.}

Figs. 1-13

Diagnosis. Body size: $564-630 \times 398-481$. Notogaster and anogenital region foveolate. Rostral, lamellar and interlamellar setae setiform, barbed; ro shortest, in longest. Bothridial seta of medium length, clavate, barbed. Humeral process tubercle-like. Ten pairs of notogastral setae developed; $c$ short, setiform, barbed; others long, uniformly flattened, bilaterally densely serrated. Epimeral and anogenital setae setiform, thin, barbed. Leg tarsus I with 20 setae (l” present).

Description of adult. Measurements. Body length: 630 (holotype, male), 564-630 (three paratypes, three males); body width: 481 (holotype), 398-481 (three paratypes).

Integument. Body color brown. Body covered by microgranulate cerotegument. Surface densely granulate microsculpturing. Anterior part of prodorsum foveate-reticulate. Notogaster, anogenital region, anal plates and partially epimeres foveolate (diameter of foveola up to 16). 


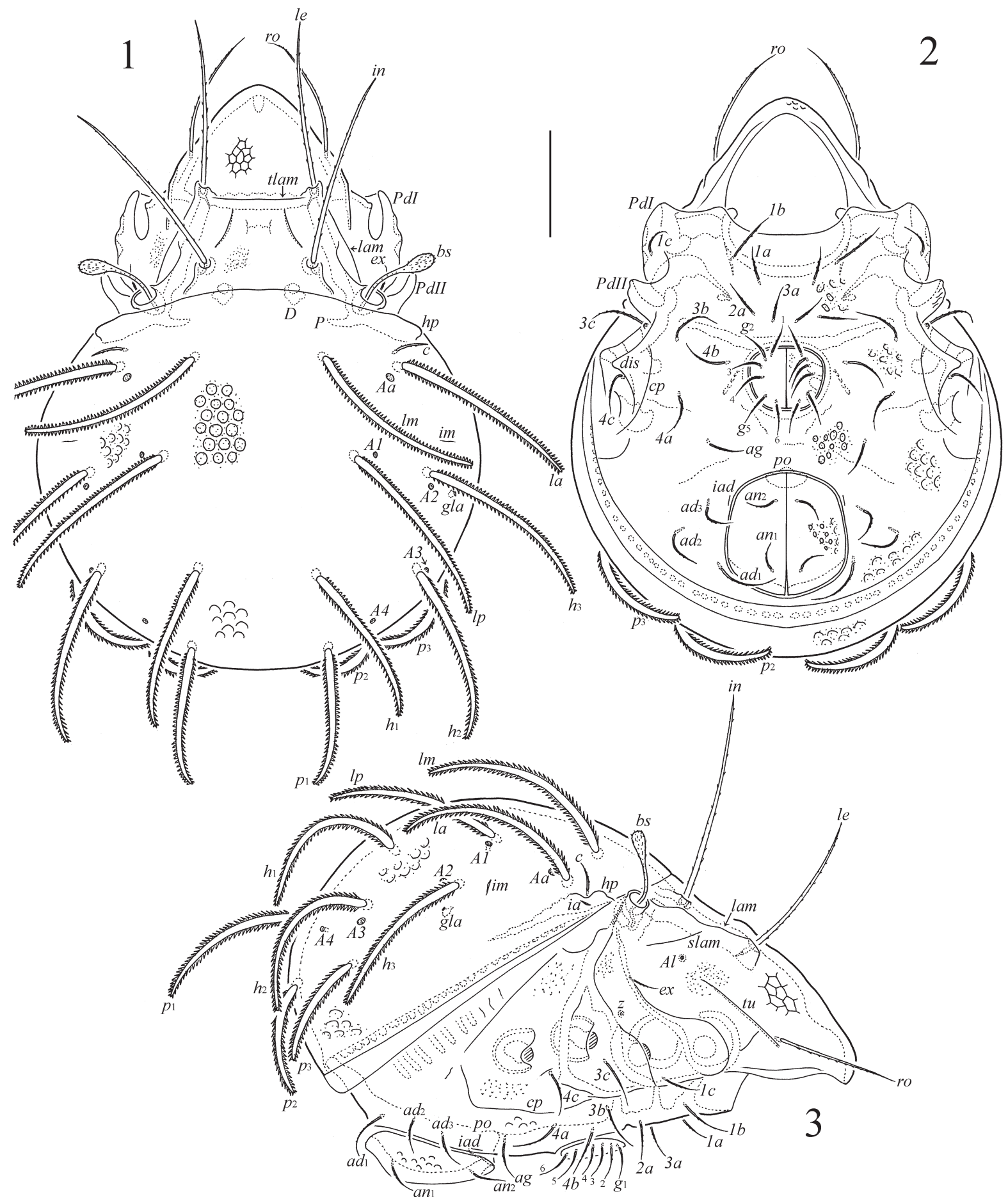

Figs. 1-3. Zetorchella ghanaensis sp.n., adult: 1-dorsal view; 2-ventral view (gnathosoma and legs omitted); 3 lateral view (gnathosoma and legs omitted). Scale bar $=100 \mu \mathrm{m}$.

Prodorsum. Rostrum broadly rounded. Lamella about $1 / 2$ length of prodorsum. Translamella lineate. Sublamella about 1/2 length of lamella. Sublamellar porose area rounded (6-8). Tutorium long, similar to lamella in length, ridge-like, distinctly not reaching rostral margin. Rostral (114-123), lamellar (147-155) and interlamellar (192-205) setae setiform, barbed. Bothridial seta (73-86) clavate, barbed; stalk longer than head. Exobothridial seta (36-41) setiform, thin, slightly barbed.

Notogaster. Anterior notogastral margin slightly convex medially. Humeral process small, tubercle-like. Ten pairs of notogastral setae developed; c (28-32) setiform, barbed, others (la, lm, lp, $\left.h_{1}-h_{3}: 180-188 ; p_{1}-p_{3}: 147-159\right)$ uniformly flattened, bilaterally densely serrated. Five pairs of 


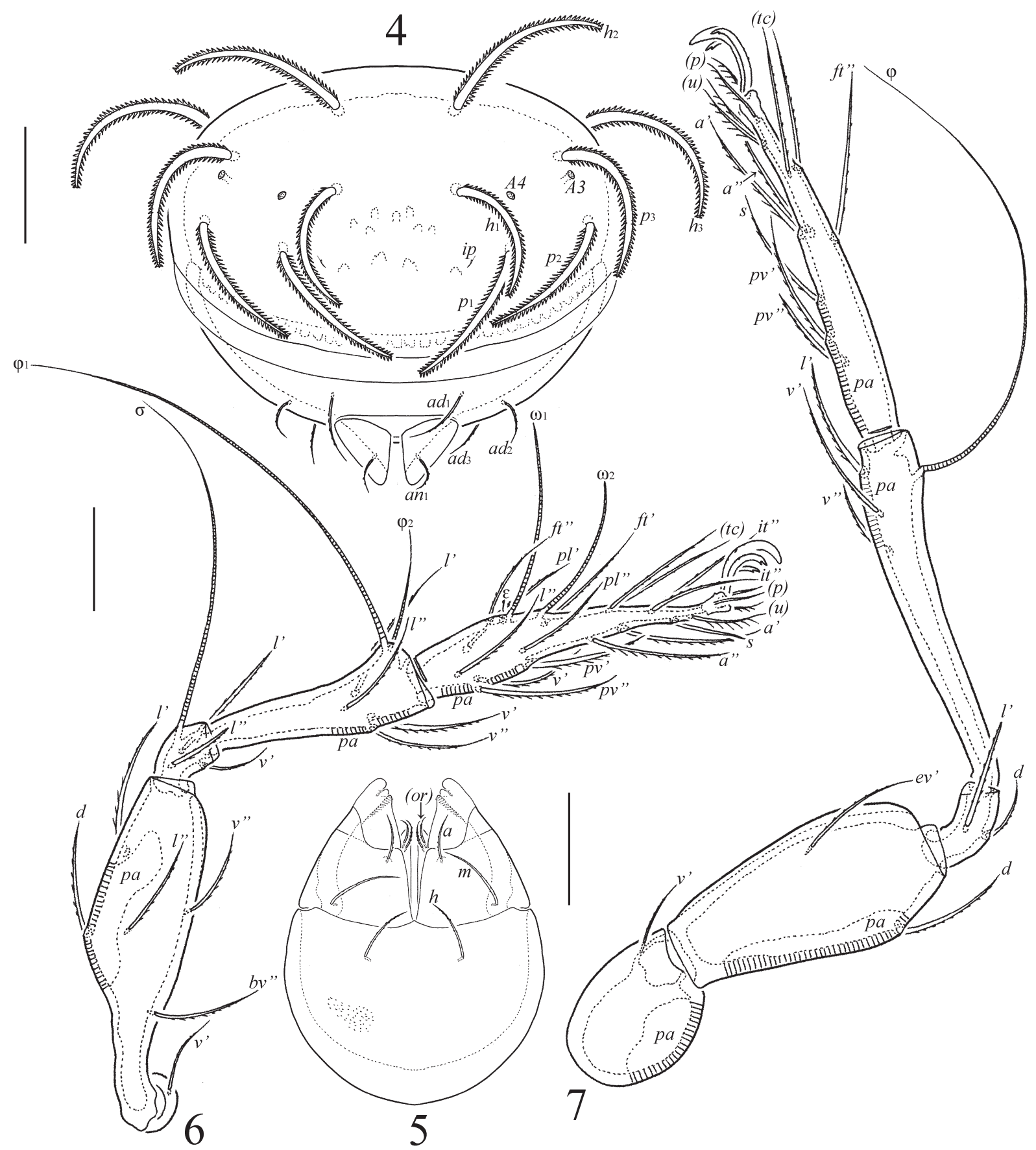

Figs. 4-7. Zetorchella ghanaensis sp.n., adult: 4-posterior view; 5-subcapitulum, ventral view; 6-leg I, right, antiaxial view; 7-leg IV, right, antiaxial view. Scale bar=100 $\mu \mathrm{m}$ (4), $50 \mu \mathrm{m}(5-7)$.

porose areas rounded (4-8). Opisthonotal gland openings $i h$ and ips not observed.

Gnathosoma. Mostly similar to other species of Zetorchella (e.g., Ermilov and N'Dri 2019; Ermilov et al. 2021). Subcapitulum size: $135-143 \times 102-110$. Subcapitular ( $a$ : 28-32; $m: 36-41 ; h: 32-36)$ and adoral (16-20) setae setiform, barbed. Palp (94-102) with setation $0-2-1-3-9(+\omega)$. Postpalpal seta (8) spiniform, roughened. Chelicera (143-155) with two setiform, barbed setae (cha: $61 ;$ chb: 41).
Epimeral and lateral podosomal regions. Epimeral setal formula: 3-1-3-3. Setae (1a, $1 c$, 2a, 3a: 32-41; others: 41-49) setiform, barbed. Circumpedal carina long, strong. Discidium subtriangular.

Anogenital region. Genital (32-41), aggenital (41-49), anal (41-49), and adanal ( $a_{1}: 53-61 ; a d_{2}$, $a d_{3}$ : 32-41) setae setiform, barbed. Adanal lyrifissure located close and parallel to anal plate. Marginal porose area absent. 

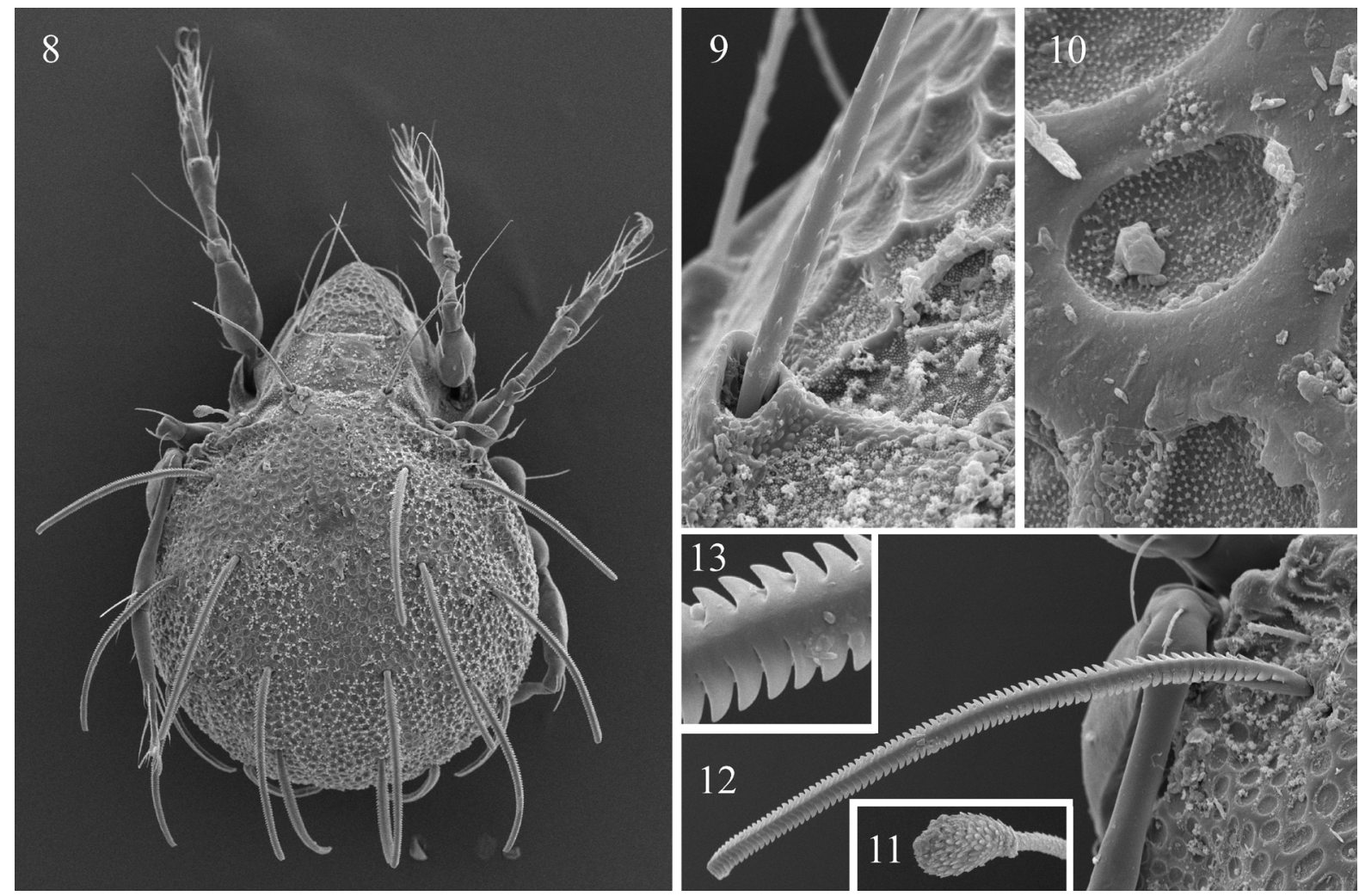

Figs. 8-13. Zetorchella ghanaensis sp.n., adult, SEM micrographs: 8-dorsal view; 9-part of prodorsum nearly insertion of lamellar seta; 10 — integument in central part of notogaster; 11 - mediodistal part of bothridial seta; 12 notogastral seta la; 13 — part of notogastral seta of la under high magnification.

Legs. Mostly similar to other species of Zetorchella (e.g., Ermilov and N'Dri 2019; Ermilov et al. 2021). Median claw distinctly thicker than lateral claws, all slightly barbed on dorsal side; each lateral claw with small tooth ventrodistally. Dorsoparaxial porose area on femora I-IV and on trochanters III, IV, proximoventral porose area on tarsi I-IV, and distoventral porose area on tibiae I-IV well observed. Formulas of leg setation and solenidia: I (1-5-3-4-20) [1-2-2], II (1-5-2-415) [1-1-2], III (2-3-1-3-15) [1-1-0], IV (1-22-3-12) [0-1-0]; homology of setae and solenidia indicated in Table 1. Famulus on tarsus I short, erect, slightly swollen distally, inserted between solenidion $\omega_{1}$ and seta $f t$ ". Seta $s$ on tarsus I eupathidial, located between setae $u$ and $a$.

Material examined. Holotype (male) and three paratypes (all males): locality 4.

Type deposition. The holotype is deposited in the collection of the Senckenberg Museum of Natural History, Görlitz, Germany; three paratypes are deposited in the collection of the Tyumen State University Museum of Zoology, Tyumen, Russia. All specimens are preserved in $70 \%$ solution of ethanol with a drop of glycerol.
Etymology. The specific name ghanensis refers to the country of origin, Ghana.

Remarks. Zetorchella ghanaensis sp.n. is morphologically most similar to Zetorchella sisiri (Sanyal, Saha and Chakraborty, 2003) from India in the presence of long, bilaterally densely serrated notogastral setae (except $c$ ). Zetorchella ghanaensis sp.n. differs in the setiform, barbed (vs. bilaterally densely serrated in Z. sisiri) lamellar and interlamellar setae and in the same length of dorsal notogastral setae (vs. dorsal notogastral setae being of distinctly different lengths in $Z$. sisiri).

\section{ACKNOWLEDGEMENTS}

The authors thank A. A. Gubin (Tyumen State University, Tyumen, Russia) for SEM micrographs. This research was supported by the cooperative agreement No. FEWZ-2021-0004, funded by the Russian Ministry of Science and Higher Education.

\section{REFERENCES}

Berlese, A. 1916. Centuria prima di Acari nuovi. Redia, 12: 19-67.

Ermilov, S.G. and Bąkowski, M. (2021) A new species of Galumnella (Acari, Oribatida, Galumnellidae) from Mozambique. Zootaxa, 5006(1): 37-44. 
Ermilov, S.G. and N'Dri, J.K. 2019. Contribution to the knowledge of the oribatid mite genus $\mathrm{Ze}$ torchella (Acari: Oribatida: Caloppiidae). Tropical Zoology, 32(1): 1-9.

Ermilov, S.G., Subías, L.S., Shtanchaeva, U.Ya. and Friedrich, S. 2021. New faunistical and taxonomic data on oribatid mites (Acari: Oribatida) of Ethiopia, with description of two new species of the superfamily Oripodoidea. Acarologia, 61 (3): 591-601.

Niedbala, W. 2008. Two new species of ptyctimous mites (Acari: Oribatida) from Ghana. African Zoology, 43(2): 131-134.

Norton, R.A. 1977. A review of F. Grandjean's system of leg chaetotaxy in the Oribatei (Acari) and its application to the family Damaeidae. In: D.L. Dindal (Ed.). Biology of Oribatid Mites. SUNY College of Environmental Science and Forestry, Syracuse, pp. 33-61.

Norton, R. A. and Behan-Pelletier, V.M. 2009. Oribatida. In: G. W. Krantz and D.E. Walter (Eds.). A Manual of Acarology. Texas University Press, Lubbock, chapter 15, pp. 430-564.

Pearce, N.D.F. 1906. VII-On some Oribatidae from the Sikkim Himalaya. Journal of the Royal Microscopical Society, 5: 269-273.
McCullough, J., Hoke, P., Naskrecki, P. and OseiOwusu, Y. (Eds.). 2008. Rapid Biological Assessment of the Ajenjua Bepo and Mamang River Forest Reserves, Ghana. RAP Bulletin of Biological Assessment 50. Conservation International, VA, USA, Arlington, 200 pp.

Sanyal, A.K., Saha, S. and Chakraborty, S. 2003. Three new species of the genus Chaunoproctus Pearce (1906) (Acarina, Oribatida) from India. Records of the Zoological Survey of India, 101 (1-2): 57-66.

Subías, L. S. 2004. Listado sistemático, sinonímico y biogeográfico de los ácaros oribátidos (Acariformes, Oribatida) del mundo (1758-2002). Graellsia, 60 (número extraordinario): 3-305.

Subías, L.S. 2021. Listado sistemático, sinonímico y biogeográfico de los Ácaros Oribátidos (Acariformes: Oribatida) del mundo (excepto fósiles), $16^{\mathrm{a}}$ actualización. 532 pp. bba.bioucm.es/cont/docs/ RO_1.pdf

Travé, J. and Vachon, M. 1975. François Grandjean. 1882-1975 (Notice biographique et bibliographique). Acarologia, 17(1): 1-19.

Wallwork, J.A. 1962. Some Oribatei from Ghana. X. The family Lohmanniidae. Acarologia, 4(3): $457-487$.

Table 1

Leg setation and solenidia of Zetorchella ghanaensis sp.n.

\begin{tabular}{|l|l|l|l|l|l|}
\hline Leg & Tr & $F e$ & $G e$ & $T i$ & $T a$ \\
\hline I & $v^{\prime}$ & $d,(l), b v^{\prime}, v^{\prime}$ & $(l), v^{\prime}, \sigma$ & $(l),(v), \varphi_{1}, \varphi_{2}$ & $(f t),(t c),(i t),(p),(u),(a), s,(p v), v^{\prime},(p l), l^{\prime}, \varepsilon, \omega_{1}, \omega_{2}$ \\
\hline II & $v^{\prime}$ & $d,(l), b v^{\prime}, v^{\prime \prime}$ & $(l), \sigma$ & $(l),(v), \varphi$ & $(f t),(t c),(i t),(p),(u),(a), s,(p v), \omega_{1}, \omega_{2}$ \\
\hline III & $l^{\prime}, v^{\prime}$ & $d, l^{\prime}, e v^{\prime}$ & $l^{\prime}, \sigma$ & $l^{\prime},(v), \varphi$ & $(f t),(t c),(i t),(p),(u),(a), s,(p v)$ \\
\hline IV & $v^{\prime}$ & $d, e v^{\prime}$ & $d, l^{\prime}$ & $l^{\prime},(v), \varphi$ & $f t^{\prime},(t c),(p),(u),(a), s,(p v)$ \\
\hline
\end{tabular}

Note: Roman letters refer to normal setae, Greek letters - to solenidia (except $\varepsilon$ - famulus), Single quotation mark (') designates setae on the anterior and double quotation mark (")—-setae on the posterior side of a given leg segment. Parentheses refer to a pair of setae. 